Gut, 1969, 10, 68-70

\title{
Importance of the size of the stoma in choledocho-duodenostomy
}

\author{
A. G. JOHNSON AND A. E. STEVENS \\ From Redhill General Hospital, Surrey, and Professorial Surgical Unit, Charing \\ Cross Hospital, London
}

Surgical opinion on the value of external choledochoduodenostomy varies from deep suspicion to wholehearted recommendation, although in recent years it has been used more widely (eg, Orr, 1966; Burgess and Kidd, 1967). Le Quesne (1964) concludes that 'there seems no doubt that the operation of choledocho-duodenostomy is safe and that it gives satisfactory results. It may well be that its merits have hitherto received too little attention'. Advocates of the operation attribute failure to an inadequate stoma and suggest the following variety of sizes as the ideal: $2 \cdot 0-3.0 \mathrm{~cm}$ (Finsterer, 1952); $2 \cdot 5-3 \cdot 0 \mathrm{~cm}$ (Capper, 1961); $2.5 \mathrm{~cm}$ (Hurwitz and Degenshein, 1964); $2 \mathrm{~cm}$ (Hosford, 1957); 1.5-2.0 cm (Fung, 1961; Hess, 1965); and 'admitting little finger' (Sanders, 1946). The complications of an inadequate stoma are ascending cholangitis, recurrent obstructive jaundice, and recurrent biliary colic and stone formation. Chamberlain in 1957 thought that the incidence of these was too high, despite a 'reasonably large' opening, for the operation to be recommended.

We have had the unusual opportunity of conducting a retrospective survey of two series of such operations performed at the same hospital, for similar conditions, nearly all by the same surgeon (A.E.S.) but with the stoma differing in size.

Of 75 cases of choledocho-duodenostomy operated on by one surgical firm at Redhill General Hospital over the last nine years (1958-67), 25 patients could not be followed up as 18 had died, 10 from the disease for which the operation was performed (seven from carcinoma of the pancreas, one from carcinoma of the gall bladder, and two from carcinoma of the ampulla). Eight died from other causes (one from carcinoma of the breast, two from heart failure, one from a stroke, one from hypertension, one from reticulum cell sarcoma, one from carcinoma of the hepatic duct, and one from unknown cause). Six did not reply to letters or could not be traced and one had emigrated to Australia. The remaining 50 could be divided into two groups: (1) those with a stoma less than $2.0 \mathrm{~cm}$ (20 cases), and (2) those with a stoma greater than $2.0 \mathrm{~cm}$ (average $2.5 \mathrm{~cm}$ ), 30 cases.

The small stomas were made before the importance of the size was appreciated or because of anatomical variations or technical difficulties. In 10 of the early cases a short length of vitellium or polythene tubing was placed in the stoma in the hope of maintaining patency in the early postoperative period. Serial radiographs on two of these showed that the tube passed into the intestine after a few weeks. In later cases the practice has been to record the stoma size in the operation notes if it was other than $2 \cdot 5 \mathrm{~cm}$.

\section{OPERATIVE TECHNIQUE AND COMPLICATIONS}

In all but one case the anastomosis was side to side, using a single layer of continuous or interrupted 00 chromic catgut. As pointed out elsewhere (Stevens and Johnson, 1967), and in agreement with Capper (1961), we have not found a double-layered anastomosis necessary. A vertical incision was made in the common bile duct and a transverse or, more recently, longitudinal, incision in the duodenum. The site of the anastomosis was always drained.

There were no operative deaths: one patient had a non-fatal pulmonary embolus, one had a temporary external fistula (but the pancreas had been biopsied), and two had significant biliary leakage through the drain which ceased spontaneously.

\section{METHOD OF FOLLOW-UP}

As many as possible of the patients were interviewed by one of us (A.G.J.) and questioned in detail about the occurrence of jaundice, rigors, pain, and indigestion. In most cases the stoma size was not known before the interview. The patency of the stoma was assessed by the presence of gas in the bile duct on a plain erect radiograph after a drink of Pepsicola ${ }^{1}$ and in some cases also by barium

'Pepsicola contains 3.6 volumes of carbon dioxide. 
meal. Those who were unable to attend for interview were sent a questionnaire which dealt with the same specific symptoms. Vague questions about 'general well-being' and 'satisfaction with operation' were avoided.

\section{RESULTS AND DISCUSSION}

The findings in the two groups are summarized in Tables I and II. The ages of the patients in the small stoma group ranged from 48 to 91 years and the time since operation from nine to three years. In the large stoma group the figures were 34-81 years and five-and-a-half years to four months respectively.

In the small stoma group re-operation was performed for recurrent obstructive jaundice (one case, four years later, when a stone was found impacted at the ampulla) and cholangitis (two cases, five and three years after first operation). Not all the patients with non-patent stomas had cholangitis and vice versa.

In the large stoma group the single case of cholangitis occurred immediately after the patient left hospital. Subsequently the stoma was readily patent to barium and there have been no further attacks in the last six months. The patient with a non-patent stoma had been completely free of symptoms for the three years since operation but

TABLE I

INDICATIONS FOR OPERATION AND PREVIOUS OPERATIONS Small Stoma Large Stoma

\begin{tabular}{lrr}
\hline Stones in common bile duct & 9 & 14 \\
$\begin{array}{l}\text { Chronic pancreatitis } \\
\begin{array}{l}\text { Dilated common bile duct with } \\
\text { stricture at lower end }\end{array}\end{array}$ & 6 & 5 \\
$\begin{array}{l}\text { Biliary fistula } \\
\text { Dilated, thickened common bile duct } \\
\text { with history of jaundice }\end{array}$ & 4 & 4 \\
$\begin{array}{l}\text { Acute or recurrent acute pancreatitis } \\
\text { Total }\end{array}$ & 0 & 0 \\
$\begin{array}{l}\text { Previous cholecystectomy alone } \\
\text { Previous cholecystectomy and } \\
\text { exploration of common bile duct }\end{array}$ & 20 & 5 \\
Previous sphincterotomy & 6 & 3 \\
& 1 & 4 \\
\end{tabular}

TABLE II

INCIDENCE OF CHOLANGITIS AND PATENCY OF STOMA AFTER OPERATION

Small Stoma Large Stoma

Stoma patent

Stoma not patent

Not tested

Total

Cholangitis

Obstructive jaundice

Re-operation performed

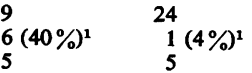

$20 \quad 30$

$\left.\left.\begin{array}{l}5 \\ 1\end{array}\right\} 30 \% 2 \quad \begin{array}{l}1 \\ 3\end{array}\right\} 3 \%$

${ }^{1}$ Percentages based on the total tested for stoma patency

Percentages based in the total in each group was too old to justify further investigations. Although it is noted that the small stoma group have been followed up on average longer than the large stoma group, the first appearances of cholangitis occurred between two months and 21 months after operation which diminishes the significance of this difference. The only case of late cholangitis, not included in the above results, demands special mention.

The patient, a woman of 65 , had a choledochoduodenostomy in 1958 for stones in the common bile duct, one of which was impacted in the bifurcation of the common hepatic duct. She was perfectly well for nine years and then developed severe cholangitis. Laparotomy revealed multiple pyaemic abscesses in the liver and a patent choledocho-duodenostomy which was not opened. Although treated by antibiotics she died six weeks after the operation and necropsy showed a papillary polygonal cell carcinoma at the bifurcation of the common hepatic duct which was partly obstructing the lumen producing a valve effect. We may speculate on the previously impacted stone and irritation from duodenal contents as possible aetiological factors.

Barium studies in eight cases confirmed the findings of the plain radiograph. A large stoma allowed barium into the common bile duct and was followed by rapid emptying, but a stoma that was not patent to gas was not patent to barium. In one case with cholangitis barium rapidly filled the whole of the biliary tree, including the small intrahepatic branches, and was still present on a three-hour film. In those cases where there were no symptoms despite a nonpatent stoma, presumably the condition which caused obstruction at the lower end of the bile duct (pancreatitis or oedema due to a stone) had resolved and bile was passing through the sphincter normally; this might have been a factor in the closing of the stoma as suggested by Burt (1953).

In only one quarter of those with a large stoma who were radiographed was the bile duct still dilated, which shows that the operation effectively reduces the pressure in the bile duct; but, if the duct is white and thickened by fibrosis at the time of operation, it would not be expected to return to normal despite adequate decompression.

The worst situation created by the small stoma is a valve-like opening through which duodenal contents can be forced but are unable to drain out.

\section{SUMMARY}

Two groups of patients who had undergone choledocho-duodenostomy were compared and the incidence of complications was related to the size of the stoma. It is concluded that a stoma of more than $2 \mathrm{~cm}$ is essential to the success of the operation. 
We are most grateful to Dr J. G. Sowerbutts for help with the radiology and to Miss $H$. A. Burt for organizing follow-up clinics and doing the secretarial work.

\section{REFERENCES}

Burgess, J. N., and Kidd, H. A. (1967). Choledochoduodenostomy in treatment of chronic pancreatitis and choledocholithiasis. Brit. med. J., 2, 607-609.

Burt, L. I. (1953). Choledochoduodenostomy in diseases involving the biliary and pancreatic ducts. Med. J. Aust., 1, 805-807.

Capper, W. M. (1961). External choledochoduodenostomy: an evaluation of 125 cases. Brit. J. Surg., 49, 292-300.

Chamberlain, D. (1957). Choledochoduodenostomy. Brit. med. J., $1,1418$.

Finsterer, H. (1952). Peut-on recommander la cholédoco-duodénostomie pour le traitement des maladies des voies biliaires? Mém. Acad. Chir., 78, 499-502.
Fung, J. (1961). Liver fluke infestation and cholangio-hepatitis. Brit. J. Surg., 48, 404-415.

Hess, W. (1965). Surgery of the Biliary Passages and the Pancreas, translated by H. Lamm, p. 365. Yan Nostrand, New York.

Hosford, J. (1957). Treatment of stone in the common bile duct. Brit. med. J., 1, 1202-1205.

Hurwitz, A., and Degenshein, G. A. (1964). The role of choledochoduodenostomy in common duct surgery: reappraisal. Surgery, 56, 1147-1150.

Orr, K. B. (1966). External choledochoduodenostomy for retained common duct stone: reappraisal of an old technique. Med. J. Aust., 2, 1027-1029.

Sanders, R. L. (1946). Indications for and value of choledochoduodenostomy. Ann. Surg., 123, 847-858.

Le Quesne, L. P. (1964), Choledocholithiasis, pp. 118-163. In Surger of the Gall Bladder and Bile Ducts, p. 160. Edited by R. Smith and S. Sherlock. Butterworths, London.

Stevens, A. E., and Johnson, A. G. (1967). Choledochoduodenostomy. Brit. med. J., 3, 109-110.

\section{The December 1968 Issue}

\section{THE DECEMBER 1968 ISSUE CONTAINS THE FOLLOWING PAPERS}

\section{Signposts}

Perfusion studies in relation to intestinal absorption $\mathbf{G}$. E. SLADEN

Cell-mediated immune reaction to colon altered by bacteria SIDNEY FINK and ROLAND F. MAIS

Presence of a non-adrenergic inhibitory system in the human colon A. CREMA, M. DEL TACCA, G. M. FRIGO, and S. LECCHINI

Gastrin, acid, and bile G. J. COLE and A. M. CONNELL

Effects of SC 15396 on gastric secretion A. M. CONNELL, R. A. HILL, I. B. MACLEOD, W. SIRCUS, and C. G. THOMSON

Part I. Inhibition of canine gastric secretion by compound SC 15396 given orally and parenterally A. M. CONNELL

Part II. Inhibitory effect of SC 15396 on stimulated canine gastric secretion after surgical procedures I. B. MACLEOD and R. A. HILL

Part III. The action in the rat C. G. THOMSON and w. SIRCUS

Effect of orally administered prostaglandin $E_{1}$ on gastric secretion and gastrointestinal motility in man E. W. HORTON, I. H. M. MAIN, C. J. THOMPSON, and P. M. WRIGHT Effect of vagotomy on the gastric secretion of acid chloride and pepsin in response to an antral stimulus and to insulin and maximal histamine stimulation F. I. TOVEY M. SWAMINATHAN, K. PARKER, and A. DANIELL

Psychological factors, operative procedures, and results of surgery for duodenal ulcer A. I. M. GLEN and ALAN G. $\operatorname{cox}$
Care of leiomyosarcoma of the duodenum and a review of the literature E. O. OLURIN and T. F. SOLANKE

Adrenergic fibres in the human intestine L. CAPURSO, C. A. FRIEDMANN, and A. G. PARKS

Insulin potentiation of the augmented histamine response R. G. CHECKETTS, I. E. GILLESPIE, and A. W. KAY

The effect of vagotomy on the human gastrooesophageal sphincter C. V. MANN and J. D. HARDCASTLE

Incidence of hiatus hernia in asymptomatic subjects $\mathrm{N}$. H. DYER and R. B. PRIDIE

Hyperparathyroidism associated with chronic pancreatitis in a family MARTIN C. CAREY and OLIVER FITZGERALD A controlled trial of carbenoxolone sodium capsules in the treatment of duodenal ulcer R. D. MONTGOMERY, I. H. LAWRENCE, D. J. MANTON, K. MENDL, and PAMELA ROWE

Bromsulphthalein metabolism in acute alcoholic liver disease PATRICIA WILKINSON, D. M. O'DAY, K. J. BREEN, and J. G. RANKIN

An immunological and histoimmunological study of gastric sulphoglycoproteins in healthy and aspirin-treated dogs I. P. T. HÄKKINEN, R. JOHANSSON, and M. PANTIO

Folic acid malabsorption in cardiac failure R. D. HYDE and C. A. E. H. LOEHRY

Comment: The stomach in vian-deficiency anaemia $\mathrm{D}$. J. C. SHEARMAN and N. D. C. FINLAYSON

Notes and activities

The British Society of Gastroenterology

Copies are still available and may be obtained from the PUBLISHING MANAGER, BRITISH MEDICAL ASSOCIATION, TAVISTOCK SQUARE, W.C.1, price 18s. 6D. 